\title{
Hepatocellular adenoma
}

INSERM

\section{Source}

INSERM. (1999). Orphanet: an online rare disease and orphan drug data base.

Hepatocellular adenoma. ORPHA:54272

Hepatocellular adenoma $(\mathrm{HA})$ is a rare benign tumor of the liver. 